\title{
From the collections: the Grove-Hills bequest
}

\section{Siân Prosser explores some cutting-edge scientific tools from the 15th century, a gift to the RAS that, in its research and outreach value, keeps on giving.}

\section{he Royal Astronomical Society has been collecting books and manu- scripts since it was established in} 1820. It now has a core collection of 4300 rare books, purchased or donated by Fellows. The 1922 bequest of the astronomer and soldier Colonel Edmond Grove-Hills is one of the most valuable donations: more than 500 books dating from 1472 to 1700 .

The collection includes 36 incunables, books printed in Europe before 1501 in the earliest days of the printing press. The incunables in the Grove-Hills collection represent an interweaving of knowledge and skill spanning centuries: the learning of the classical and medieval scholars whose works were transmitted in manuscript and then in print. They include examples of innovations in scientific publishing - multicoloured figures and paper instruments - that made these volumes the cutting-edge scientific tools of their day. Now they provide a window into 15th-century scientific thought that is valuable for outreach as well as research.

Grove-Hills (see the box "Who was Grove-Hills?") published his own research only on the results of solar eclipse expeditions, the movement of the poles and other scientific matters, but the contents of the library collection that he left to the RAS show that he was a very knowledgable bibliophile in the domain of history of science. His collection was arranged and catalogued at Burlington House by Kathleen Williams, the assistant secretary of the RAS, under the supervision of Edward Ball Knobel who was chair of the Library Committee at that time and a book collector himself. While there is little evidence of what motivated Grove-Hills to choose the books he collected, the design of his book plates offers some clues.

It includes the initials EHH on the coat of arms with, in the background, some subtly engraved hills. The words "Bibliotheca

\section{Who was Grove-Hills?}

Edmond Herbert Hills (he adopted the name GroveHills later in life), was born into a privileged background in High Head Castle, Cumbria, in 1864. Both his father and grandfather were judges; his grandfather Sir William Grove was also an active member of the Royal Institution. His brother John Waller Hills married Stella Duckworth, the half-sister of Virginia Woolf and Vanessa Bell.

Grove-Hills attended

Winchester School and the Royal Military Academy before obtaining a commission in the Royal Engineers at the age of 20. He stayed in the army until he was 41 and spent most of his army career teaching photography and chemistry at the School of Military Engineering. He also worked for the War Office where, as an expert surveyor, he oversaw the production of maps for the Boer War. He also had a strong research interest in geodesy. After he left the army in 1905, he became involved in survey work in Canada, Sri Lanka and Uganda, using his scientific knowledge in support of the British Empire (Collier 2006).

He joined the Royal Astronomical Society in 1893, as a result of his innovative photography of eclipses. Eclipse expeditions tended to be lengthy and trying, but according to fellow astronomers Grove-Hills would liven them up with his "famous fish story" or by recalling the time his son nearly poisoned him with mystery mushrooms. Other anecdotes have not aged well.

Grove-Hills served on the RAS Council for many years. When he was President he

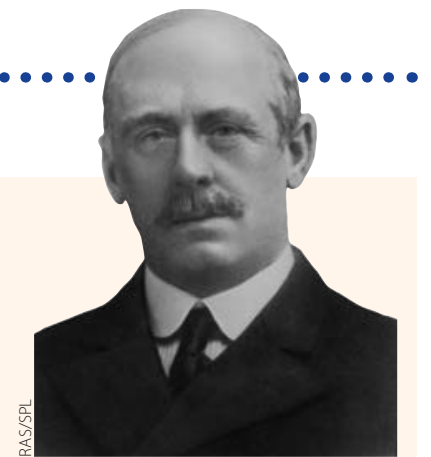

moved for women to be elected as Fellows in 1916. When Treasurer, he worked to put the RAS on a sound financial footing when it was at risk from increases in journal printing costs and the economic fall-out of the 1914-18 war. In 1920, he inherited his maternal uncle's large estate and changed his surname to Grove-Hills. He died of pancreatic cancer in 1922 at the age of 58. He and his wife Juliet had two sons who both died in the 1914-18 war, Charles Herbert in 1916, and William Frederick Waller in 1917; a daughter, Julia, survived him.

Astronomica" in a bold style of lettering and astronomical imagery, including an armillary sphere on a table with books, are reminiscent of the woodcuts in key texts in astronomy up to the end of the 17th century, including those by Euclid, Copernicus, Kepler, Galileo and Newton. Many of these can be found in the Grove-Hills collection.

They include innovations such as multicoloured figures and paper instruments"

Abū al-Ábbās Aḥmad ibn Muhammad ibn Kathīr al-Farghānī and Thābit ibn Qurra. At first disseminated through manuscripts copied by hand, the book was one of the first scientific works to be published using

\section{'De Sphaera'}

Among the 36 incunables, there are five editions of Tractatus de Sphaera by Johannes de Sacrobosco, also known as John of Holywood, who taught astronomy at the University of Paris in the 13th century. De Sphaera is an astronomy textbook that draws on the Aristotelian and Ptolemaic geocentric models of the solar system, and on later works such as those of two 9th-century scholars based in Baghdad, at the top of the mast will see the shore ing. It begins with a section on the spherical nature of the Earth, including woodcut diagrams of a boat, demonstrating that someone standing before a person on deck. When members of the public visit the RAS Library to learn about the history of astronomy and see this diagram, they appreciate this evidence that people with access to education in the ancient and medieval worlds had deduced that the Earth is not flat.

Grove-Hills had 34 editions of De Sphaera altogether, including the five pre- 1500 copies; it is perhaps not surprising that a 

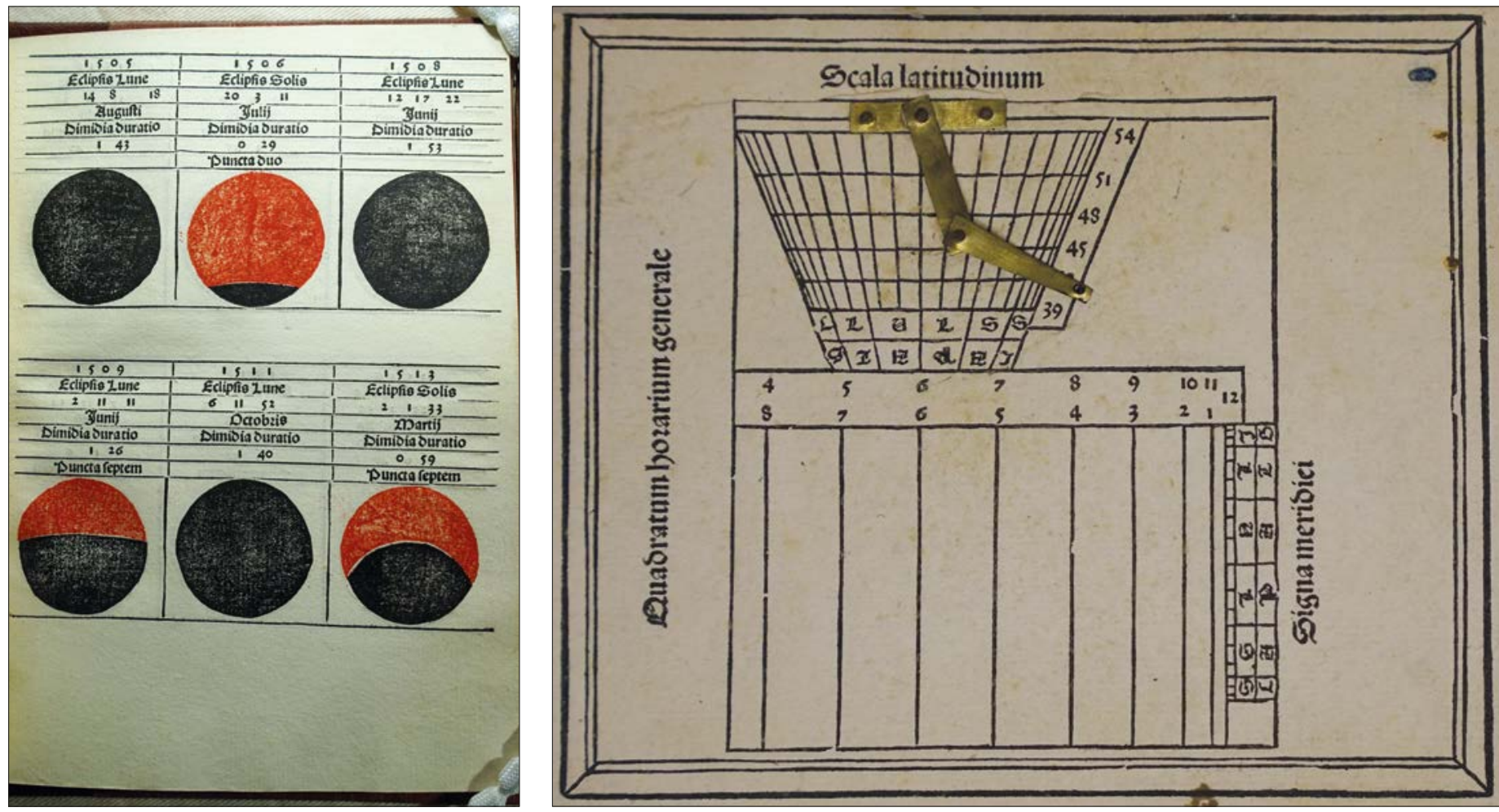

1 (Left) Coloured diagrams of partial eclipses of the Sun and partial and total eclipses of the Moon predicted by Regiomontanus in the 1499 edition of Kalendarium, printed by Ratdolt in two colours, an innovative technique which first appeared in 1485.

2 (Right) Also from Kalendarium, a design for a portable sundial constructed on a flat plane. The jointed brass pointer, or brachiolus, can be adjusted against the top part of the grid for the correct latitude and date. The pointer has a hole in the end for a plumb line. In practice, the sundial would be held vertically with the top edge aligned with the Sun's rays. Then the time of day can be determined by the position of the plumb-bob against the lower part of the grid.

professional geodesist would acquire books containing depictions of the figure of the Earth. The 1485 edition is accompanied by another tract called Theoricae Novae Planetarum by Georg von Peurbach (1423-61), about the motions of the planets and the theory of eclipses, also among Grove-Hills' research interests.

The eclipse diagrams in this edition are not only of scientific interest, but are significant to the history of printing, because they represent some of the earliest examples of multicolour printing by the innovative and prolific printer Erhard Ratdolt (1452-1528), 10 of whose editions are in the Grove-Hills collection. Ratdolt spent his working life in Venice and Augsburg and his other inventions included the title page. The first printers had followed the custom of their predecessors, scribes, who included details such as author, publisher and date of printing at the end of the book. Both two-colour eclipse diagrams and a title page (printed in red) feature in another of Ratdolt's publications in the collection, the Kalendarium (1499; figures 1 and 2) by Johannes Müller of Königsberg (1436-76), otherwise known as Regiomontanus.

\section{Regiomontanus}

Regiomontanus was an outstanding astronomer and linguist who, along with his collaborator Georg von Peurbach, and

at the instigation of the humanist cardinal Johannes Bessarion (c.1395-1472), dedicated himself to revising authoritative astronomical texts and compiling new, accurate ephemerides, correcting the mistakes introduced through centuries of scribal copying. He opened a print shop in Nuremberg.

"The Grove-Hills collection is a jewel within the Library and Archive collections"
While the edition of the Kalendarium was printed by Ratdolt, not Regiomontanus, it contains ingenious printed instruments originally designed by Regiomontanus, such as a portable sundial constructed on a flat plane, with an articulated brass pointer or brachiolus with a hole in the end, to which a string carrying a bead would be attached (figure 2). Today, sundials of this type are known as Regiomontanus dials. A much greater impact was created by his work with Peurbach to develop a new version of Ptolemy's Almagest, the Epitome, finally published decades after the deaths of the authors in 1496 and also represented in the Grove-Hills collection. Nicolaus Copernicus (1473-1543) owned a copy of this book and it informed his understanding of and critical engagement with planetary theory.

The works of Regiomontanus and Ratdolt, celebrated names in early scientific publishing, are prominent in this small collection of incunables, and it must have taken a considerable amount of focus on Grove-Hills' part to obtain these works, even at a time when history of science books were less sought-after.

The RAS celebrates its bicentenary in 2020; the Grove-Hills collection is a jewel within the Library and Archive collections amassed over 200 years. It stands as an example of philanthropy from the end of the first century of the Society's existence that holds its scientific and historical value at the start of the third. The collection - and the incunables especially - are part of a gift to the Society that will keep on giving if we use these books in our aim to promote the understanding of astronomy and geophysics, and the history of these subjects, in the course of education and outreach activities as well as making the texts available to expert researchers. $\bullet$

\section{AUTHOR}

Siân Prosser is Librarian and Archivist of the RAS, sprosser@ras.ac.uk @astro_librarian.

\section{FURTHER READING}

British Sundial Society glossary http://sundialsoc.org.uk/

discussions/glossary-a-z

Collier P 2006 in Old Worlds-New Worlds: the History of Colonial Cartography 1750-1950 (Utrecht University) 21 to 23 August 2006 Hoskin MA (ed.) 2000 The Cambridgelllustrated History of Astronomy (Cambridge University Press, New York)

Hutchins R 2004 Edmund Herbert Grove-Hills in Oxford Dictionary of National Biography (OUP)

Obituary 1922-23 Mon. Not. R. Ast. Soc. 8324

Stijnman A \& Savage E 2015 Printing Colour 1400-1700: History,

Techniques, Functions and Receptions (Brill, Leiden)

The Sphere: Knowledge System Evolution and the Shared Scientific Identity of Europe https://sphaera.mpiwg-berlin.mpg.de Zinner E \& Brown E 1990 Regiomontanus: His Life and Work (New Holland) 